\title{
Cooperation between Social Entrepreneurs and Government to Develop Solutions to Social Problems
}

\author{
Iza Gigauri \\ Associate Professor, School of Business, Computing and Social Sciences \\ St. Andrews Georgian University, Tbilisi, Georgia \\ ORCID: https://orcid.org/0000-0001-6394-6416 \\ E-mail: i.gigauri@sangu.edu.ge \\ Nino Damenia \\ Professor, School of Business, Computing and Social Sciences \\ St. Andrews Georgian University, Tbilisi, Georgia \\ E-mail: n.damenia@sangu.edu.ge
}

Received: June 18, 2020 Accepted: July 13, 2020 Published: July 21, 2020

doi:10.5296/ber.v10i3.17383 URL: https://doi.org/10.5296/ber.v10i3.17383

\begin{abstract}
Entrepreneurship and innovation tend to serve as vehicles to provide solutions to economic woes during recession without relying upon public resources. The article discusses the definition of social entrepreneurship and shows how social entrepreneurship has developed at the relation of private, public, and nonprofit sectors. It outlines main trends in social entrepreneurship, and highlights successful entrepreneurial initiatives in solving social problems. The paper also examines how social entrepreneurship can help government to benefit society and improve lives. Government and social entrepreneurs have a common goal to solve social problems in effective and efficient way. However, little has been researched on this relationship. The presented article emphasizes that government can support social entrepreneurial initiatives in various ways to encourage social entrepreneurs to innovate, as well as create enabling environments for their efforts to solve problems in society.
\end{abstract}

Keywords: Social entrepreneurship, SE, Entrepreneur, Nonprofits, Government, Developing countries, Georgia 


\section{Introduction}

The field of social entrepreneurship has experienced immense growth over the past years around the world, and has received increasing recognition from public, private, and nonprofit sectors, as well as from researchers, academics, and policymakers (Wolk, 2007).

Social entrepreneurship emerged as an innovative form of business that is the successful compound of social aims and commercial goals (Kostetska \& Berezyak, 2014). Social entrepreneurship responds to lasting social problems such as unemployment, poverty, environmental pollution and other ecological issues. Social entrepreneurship comes into play when governments cannot act because of the scarcity of finance, and when the business in not interested to perform due to the low profitability (Kostetska \& Berezyak, 2014). Social entrepreneurship is considered as "the practice of responding to market failures with transformative, financially sustainable innovations aimed at solving social problems" (Wolk, 2007).

Thus, Social entrepreneurship offers an alternative for solving market failures, and moreover, it can be viewed as the commercial opportunity (Wolk 2007; Phills \& Denend, 2005) that social entrepreneurs take to yield results. Entrepreneurs are problem-solvers, lifetime learners, change-makers, who have capacity of creating better future for all.

New approaches are emerging at the nexus of the public and business sectors combining them into social ventures (Villis et al., 2013). In 2011, 60 impact investing funds were created, raising the combined total capital available for social investments to an estimated $\$ 40$ billion (Clark et al., 2012). Moreover, the European Commission estimates that 1 out of 4 new enterprise every year in the European Union is social enterprise (European Commission, 2012), and intends to create favorable conditions for their development and operation.

Since the environmental and social problems around the globe are complex and enormous, people doubt that institutions have capabilities to improve the conditions (Seelos \& Mair, 2005). But entrepreneurial initiatives challenge this existing situation as well as widespread view about the feasibility what can be achieved (Seelos \& Mair, 2005).

Many countries are still facing incredible societal challenges and needs, especially those in developing or emerging economies. For example, more than $20 \%$ of Georgian population lives under absolute poverty line (Geostat). 821 million people - 1 out of 9 of the world population, do not have sufficient food (UN World Food Programme - WTF, 2019).

Nowadays, many social companies in both developing and developed countries are taking their first steps, however some of them have already incomes in millions with thousands of employees, which indicates the potential of the business (Villis et al., 2013).

In order to achieve financial sustainability, nonprofit organizations are establishing social enterprises. It becomes difficult to raise funds from donors, international grantmakers, private foundations, corporations, and/or government agencies. Besides, strong dependence on donors can result in changes in programs or projects of a nonprofit organization in accordance with grant requirements. This can hinder their effectiveness and efficiency in 
implementing their mission. Accordingly, the organization can hardly achieve development and sustainability in long-term.

Within this context, social entrepreneurship has attracted particular attention. The idea of social enterprise involves companies with a main goal to address a social problem with the business approaches (Villis et al., 2013).

One of the main markers of success of any country, irrespective of its social or economic development, is the social stability of society (Kostetska \& Berezyak, 2014). So social entrepreneurship as a social innovation became topical.

Government and social entrepreneurs have a common goal to solve social problems in effective and efficient way. However, little has been researched on this relationship by scholars. The aim of the paper is to explore theoretical grounding of need and viability of social entrepreneurship as an engine for development people-centered economy, as well as to discover the role of government in promoting its implementation. The research reveals the broader opportunities of social entrepreneurship in resolving the social problems.

The presented article aims at answering the following research questions: (1) how private, public and nonprofit sectors are connected to the concept of social entrepreneurship? (2) How does social entrepreneurship solve social problems of society, especially in Georgia as an example of developing countries? (3) How does a government create favorable conditions for social enterprises so that they can solve social problems effectively? (4) How do social entrepreneurs help a government to meet social needs of their country?

To answer these questions, literature in the field of social entrepreneurship has been reviewed, and secondary data from different sources in related areas have been gathered and analyzed. Finally, recommendations and conclusion is presented.

\section{Advancement of Social Entrepreneurship}

Social entrepreneurship is of great importance for the progress of society, just as entrepreneurship is for the progress of the economy (Martin \& Orsberg, 2007). Economist Joseph Schumpeter argued that "the function of entrepreneurs is to reform or revolutionize the pattern of production by exploiting an invention" (Schumpeter, 1982). Entrepreneurship is described as a process initiated and carried out by an individual, for the purpose of identifying, evaluating, and utilizing entrepreneurial opportunities (Fueglistaller et al., 2016).

The phenomenon of social entrepreneurship arose in the United States of America (Dees \& Anderson, 2007), and has developed under various names (Wolk, 2007). In 1983, Edward Skloot invented the term "nonprofit entrepreneurship" in his article where he explained the ability of business enterprises to diversify sources of financing for nonprofit organizations, and which was based on his pioneering consulting work with nonprofit organizations interested in creating business ventures in 1980 (Wolk, 2007; Skloot, 1983). Besides, private-sector consultant Bill Drayton founded Ashoka in 1981 to support innovators he called "public entrepreneurs," and later named them "social entrepreneurs" (Anderson \& Dees, 2006). Moreover, management expert Peter Drucker described entrepreneurship as a 
concept that spread across several sectors without setting limits on profit-seeking, commercial ventures (Drucker, 1985; Wolk, 2007).

Seelos and Mair (2005) offer the following definition: "Social entrepreneurship creates new models for the provision of products and services that cater directly to basic human needs that remain unsatisfied by current economic or social institutions". Like business entrepreneurship, social entrepreneurs recognize and act upon what others may omit: chances to improve structures, systems, and procedures; invent solutions; create new approaches. According to Fueglistaller et al. (2016), social entrepreneurship is an approach to solving social problems in an entrepreneurial way. In contrast to commercial or traditional business companies, the primarily pursues of which are financial goals such as increasing profits and enterprise value, social entrepreneurs form organizations with the primary goal of creating added value for society. However, many SMEs and large companies also take into account social aspects of their business and create social added value. But social enterprises put the creation of social benefits in the first place.

The term 'social entrepreneurship' (SE) refers to the organizations that create business models to effectively meet fundamental human needs, which are dissatisfied by existing markets, and hence SE brings together the ingenuity of traditional entrepreneurship with a mission to transform society (Seelos \& Mair, 2005).

Zahra et al (2009) offer the following definition: "Social entrepreneurship encompasses the activities and Processes undertaken to discover, define, and exploit opportunities in order to enhance social wealth by creating new ventures or managing existing organizations in an innovative manner".

Social entrepreneurs try to alleviate and to solve basic human needs such as unemployment, poverty, malnutrition, hunger, and educational or medical issues. Unlike a charity, social businesses are designed with the purpose of reinvesting profits to implement their social missions, and of being financially self-supporting (Beal et al. 2017). It should be highlighted that Social Business is a special form of Social Entrepreneurship, and although both fields are dedicated to mitigation of social problems, they differ in their attitude to using of donations (Fueglistaller et al., 2016). According to Muhammad Yunus (2010), social business possesses three characteristics: they are non-loss, non-dividend companies with social objectives, they expect profit; thus, they do not distribute profits to shareholders, and pursuing a social goal is paramount.

Beal et al. (2017) found that when companies launching social business branches to induce changes, the initiative has an impact not only on the community but also produces definite benefits to the parent company. Thus, social entrepreneurship can facilitate firms to provide value to people in need, and at the same time discovering value for their business (Beal et al., 2017). Throughout the value chain, companies frequently uncover that their new products, systems, models, methods, or strategies intended for those population can also be a source of competitive advantage (Villis et al., 2013).

In spite of various definitions of social entrepreneurship, the most definitions assume that 
they create social wealth through innovation of business models or diverse entrepreneurial means while they try to mitigate or solve urgent societal problems.

\section{Intersection Of Private, Public And Nonprofit Sectors}

Lack of education, climate change, insufficient medical care, malnutrition, and poverty - the facts are frightening and shameful. Despite of aid programs developed by nonprofit and international organizations that have been dealing with the problems for decades, they can be considered as weak, ineffective or even cynical (Fueglistaller et al., 2016). However, those problems have been become entrepreneurial opportunities for social entrepreneurs. Since the field has been retaining attention from both researchers and practitioners, and discussion on the exact definition proceeds. Many definitions concur that SE has characteristics of private, public, and nonprofit sectors simultaneously, demonstrating features of each of them (Wolk, 2007; Dees, 2001). Therefore, social entrepreneurship is understood as a multi-dimensional and dynamic concept moving across various intersection points between the public, private, and social sectors (Wolk, 2007; Nicholls, 2006).

Social entrepreneurs alone cannot respond to all social challenges. This requires a meaningful interaction between all social and economic actors such as traditional entrepreneurs, nonprofit/ nongovernmental organizations (NGO), governments and international organizations (Fueglistaller et al., 2016). In addition, many pressing social problems around the globe are so deep-rooted and widespread that solely governments and traditional nonprofit organizations cannot solve them. In order to address those problems, both the private and public sectors must act together applying various approaches (Villis et al. 2013). Consequently, new models are emerging to combine business concept with social goals, and hence, to link the social and private fields (Villis et al. 2013). According to Villis et al. (2013) social businesses fall somewhere between traditional NGOs and for-profit companies (Table 1).

Table 1. Social Entrepreneurship at the crossing of non-profit and business sectors

\begin{tabular}{|l|l|l|l|}
\hline & NGO & Social Entrepreneurship & Business \\
\hline Primary objective & Social impact & Social impact & Commercial success \\
\hline $\begin{array}{l}\text { Products/ services } \\
\text { priced for sale }\end{array}$ & No & Yes & Yes \\
\hline Business model & N/A & Price $\geq$ Costs & Price > Costs \\
\cline { 2 - 4 } & $\begin{array}{l}\text { Maximizes social impact } \\
\text { Funded through donations }\end{array}$ & $\begin{array}{l}\text { Maximizes social impact } \\
\text { Financially self-sustainable }\end{array}$ & $\begin{array}{l}\text { Ensures social standards } \\
\text { Maximizes profitability }\end{array}$ \\
\hline
\end{tabular}

Source: BCG Analysis in Villis et al., 2013.

Like NGOs/ nonprofit organizations, the primary objective of social enterprises is to have social impact while operating as a business aiming to generate revenues to cover costs, reach financial sustainability, and increase effectiveness (Villis et al., 2013). Since social ventures do not have a goal to deliver financial value to shareholders, and they are also independent 
from external funding and donors, they can completely concentrate on the segments that are not covered by traditional business (Villis et al., 2013).

\section{Social Entrepreneurship Addressing Market Failure}

Social entrepreneurship like small business inspires innovation, creates jobs, and promotes economic progress (Wolk, 2007). Furthermore, social entrepreneurs combining attributes of the public, private, and nonprofit sectors, respond to market failure (Wolk, 2007), which takes place when goods and services are priced higher than people can afford to pay, but they are necessary for a healthy society (Gruber, 2005). Besides, governments transfer more tasks to business by economic liberalization, privatization, and industry deregulation (Markman, Waldron \& Panagopoulos, 2016). Moreover, since pressure is increasing on companies' responsibility regarding their ecologic, social, ethical behavior, nonmarket players such as NGOs and social entrepreneurs can be considered as a competition forces to them.

Dees (2001) explains the essential elements of social entrepreneurship: "Markets do not do a good job of valuing social improvements, public goods and harms, and benefits for people who cannot afford to pay" (Dees, 2001). Other researcher confirm this idea: "Unlike the entrepreneurial value proposition that assumes a market that can pay for the innovation, and may even provide substantial upside for investors, the social entrepreneur's value proposition targets an underserved, neglected, or highly disadvantaged population that lacks the financial means or political clout to achieve the transformative benefit on its own" (Martin \& Osberg, 2007). Seelos and Mair (2005) echoed this: Social value creation is a fundamental objective in social entrepreneurship, while creating commercial value is a byproduct only for reaching self-sufficiency. Economic value creation for social entrepreneurship is often small as its customers are unable to pay (Seelos \& Mair 2005). Seelos and Mair (2005) identified two fundamental rules that apply for highlighting differences in developed and developing countries. (1) In developed countries, people are not willing to pay for some goods or services, for example, in spite of the free services "dotcom" startups created and used by a large amount of people, it was impossible to capture fees for the service; (2) In non-industrialized countries, on the contrary, customers are ready but unable to pay for even basic products or services (Seelos \& Mair 2005). In order to address this failure, an increasing amount of initiatives all over the world defy the impediments that have prohibited business sector from offering services to the poor (Seelos \& Mair, 2005). Those initiatives facilitate the development of SE, aimed to discover inspired models of value creation, and combine resources in new ways (Seelos \& Mair, 2005).

In developing countries, many initiatives cannot be implemented because of the lack of structure or resources enabling or supporting by traditional entrepreneurship. But social entrepreneurship can create innovative business models, new organizational systems and strategies to create social value with limited resources (Seelos \& Mair, 2005).

Wolk (2007) has identified three approaches how social entrepreneurs respond to market failures: No Market, Limited Market, and Low-profit Market. To solve a social problem with a no-market approach is used when the customers of a certain product and service is unable to pay (Seelos \& Mair, 2005). Consequently, this approach takes the form of the government 
lead or nonprofit organizations as a social entrepreneur who selects no-market approach cannot earn revenue from the beneficiary to sustain the initiative (Wolk, 2007). When the customers are able to pay, a limited-market occurs. Accordingly, social entrepreneurs can earn some revenues to maintain the enterprise. Usually, limited-market approach is used by nonprofit sector (Wolk, 2007). Unlike to no-market or limited market approaches, in a low-profit market, customers are able and willing to fully pay the costs when solving a social problem and, hence, it is possible to make a profit (Wolk, 2007). Nevertheless, the market may not be well developed, or investments may generate lower returns than commercial enterprises (Wolk, 2007). This approach can take both the for- or non-profit sectors. The low-profit market approach ultimately develops the market enough for businesses (Wolk, 2007).

\section{Social Entrepreneurs and Innovation}

Social entrepreneurship is related to sustainable development as they develop new products, discover new markets, and introducing innovations (Méndez-Picazo et al., 2020).

Scholars focus on innovation while describe social entrepreneurship. Social innovation involves creating novel ideas, new services or advanced models to solve social problems (European Commission, 2020). Social innovation refers "to a product, production process, idea, social movement or a combination" of them to better drive positive social change (European Commission, 2020). In this regard, the concept relates to the term social entrepreneurship. Social entrepreneurs in the same veins as business entrepreneurs look for opportunities to create value, but more social than merely economic value (Wolk, 2007). It is also worthy of note that social entrepreneurship depends on people with exceptional skills at mobilizing financial, human, or political resources (Seelos \& Mair, 2005). Social entrepreneurs in common with business entrepreneurs have creative thinking, aspiration for innovation including novel technologies and production methods (Dees, 2001; Wolk, 2007). Innovative ideas also involve launching a start-up or developing novel goods (Mair \& Marti, 2006; Peredo \& McLean, 2006; Dees, 2001). Innovations can be totally new conception as well as original adaptations of ideas that already exist (Peredo \& McLean, 2006; Wolk, 2007). According to the recent research of Halberstadt and colleagues (2020), social innovativeness exert influence upon economic performance of start-ups taking into consideration various angles to create entrepreneurial innovations and find solutions.

Social entrepreneurs are creating huge changes through pattern-breaking concepts (Light, 2007), and focusing on the origins of social problems (Dees \& Anderson, 2007). Moreover, their ambitions lead to systematic changes encouraging others to adopt their new ideas (Kramer, 2005). They are change agents (Ashoka) who modify the existing social structures that have created problems (Alvord et al., 2004). Furthermore, innovations originated for entrepreneurs are constantly (Wolk, 2007). Thus, the transformative social innovation characteristic of social entrepreneurship distinguishes it from nonprofit, business, or government service providers (Wolk, 2007).

According to Dees (2001), social entrepreneurs are change agents for the following factors: they embrace a mission of creating and maintaining social value; they recognize and pursue 
fresh opportunities to implement their mission; they engage in constant innovation and learning process; they act fearlessly; and they show responsibility to customers they serve and for the outcomes created.

Social entrepreneurship initiatives are valued by today's generation, and thus, is likely to expand further. Millennial generation prefer to actively engage in a cause campaign by encouraging others to support it. For them, sense of purpose plays a vital role and determines their career choice (Barton, et al. 2012).

According to Stecker (2014), generation Y as well as Millennials are looking for jobs in social enterprises. Young people tend to choose profession that gives a sense of meaning (Smith \& Aaker, 2013; Stecker, 2014). Social entrepreneurship offers not only a sense of meaning in terms of social value, but also career success.

Social entrepreneurship is related with youth representing idealistic nature (Bosma et al., 2016). The Global Entrepreneurship Monitor (GEM) results have shown that a great number of young people (18-34 years old) choose the path of social entrepreneurship rather than profit oriented business (Bosma et al., 2016).

Recent advances in technology and communication tools have enabled social entrepreneurs to encourage supporters, engage in social networking and online communities where they can exchange information. The establishment of digital tools has made possible to connect with distinct populations (Bernholz et al., 2010). As a result of these technological developments, for example, social entrepreneurs can organize crowd-funding and large-scale collaborations in behalf of others. Thanks to networked citizens even in the most remote areas smaller communities are able to find and carry out solutions (Bernholz et al., 2010).

According to the conducted research by Villis and colleagues (2013), the essential benefits social entrepreneurship are providing is its capacity for learning and innovation. Social entrepreneurs employ entrepreneurial opportunity while bearing in mind social institutional and social context. In this regard, Robinson (2006) ascertains three themes: social entrepreneurs recognize possibilities in social and institutional contexts; they consider social and institutional aspects in the course of evaluation of opportunities to create social enterprises; and they overcome social and institutional difficulties during the process of exploring new social venture opportunities.

Thus, entrepreneurs share common initiative all over the world such as their willingness and strong desire to challenge the status quo and improve the wellbeing.

\section{Managing Outcomes}

Financial sustainability is another essential task for social entrepreneurship to maintain enough potential for serve society. Many social entrepreneurs perform cost-benefit analyses, report on social return on investment, or measure financial success that eventually helps in optimization of resources and maximization of results (Wolk, 2007).

Additionally, investors want proof that their capital is delivering financial as well as social and environmental returns. This trend forces social enterprises to display and to enhance 
impact. Therefore, social entrepreneurs have begun to manage outcomes, and are learning over time to become more effective (Morino, 2011). According to the Report of Global Entrepreneurship Monitor (GEM), about half of the social entrepreneurs state that they measure social and environmental impact of their operations (Bosma et al. 2016). Since funders progressively demand the results and outcome information, organizations need to show impact to have advantage (Morino, 2011). Besides, outcome measurement and data gathering process is important for the organizations seeking to improve the quality of services (Morino, 2011). However, this can be the most difficult task especially for nonprofit organizations. Often this procedure compels changing in organizational culture so that nonprofits do not implement it only for fulfill funding conditions as currently they collect data mostly to satisfy their diverse funders (Morino, 2011). Yet nonprofits need to collect not only those data that are required by funders in the short term, but also they should evaluate outcomes for defining the improvement possibilities of their services in the long term (Morino, 2011). Thus, they should have the data, the tools, and the commitment in place when it comes outcome management systems.

Social entrepreneurs are transformative with novel solutions that can be measured and scaled (Bornstein, 2007). Managing impact for a social enterprise aims to find out if goals are reached successfully, and whether success is sustainable. Success is providing social impact without financial aid, and to measure and manage outcomes (Villis et al., 2013). Measuring both the outcomes and impact has acquired great importance for investors too (Bernholz et al., 2010). They want to determine the quality of the grantee outcomes. Since there are measuring tools for social impact, the tendency to measurement is growing (Bernholz et al., 2010).

As all organizations whether for-profit or nonprofit create economic, social, and environmental value, investors are providing capital to organizations taking into consideration all three components. According to Bernholz et al. (2010), the concept of mixed value, resolving the conflict between market and non-market urges, can become normality.

In general, social capital is built when "funders and enterprises support one another, cooperate, and collaborate" to solve problems (Bernholz et al. 2010).

\section{Government and Social Entrepreneurs}

Governments having many roles and limited resources (Bozhikin et al., 2019) need to decide in favor of their voters using tax revenues efficiently (Wolk, 2007). Simultaneously, they should take into account the degree of needs and the amount of expenses. Both government agencies and social enterprises concern about the solving social problems efficiently, effectively and sustainably (Wolk, 2007).

In European countries, the relations between the government and social entrepreneurs have been affected by alterations in welfare states caused by the need to improve efficiency in a changing environment characterized by aging citizens, social exclusion, constant joblessness and austerity (European Commission, 2016). Social entrepreneurship is social innovation serving as an engine for social changing as well as sustainable economic development (Kostetska \& Berezyak, 2014). 


\section{Macrothink

The private sector including corporations, entrepreneurs, and small businesses utilize markets to trade goods or services in order to earn profit but also to contribute to the economy. Business is also characterized by increasing innovation. In case, the private sector cannot meet societal needs because goods and services they provide cost more than customer are capable or willing to pay, a market failure takes place (Wolk, 2007). Government's role is seen to address such market failures, and provide those services and goods that do not generate profit. In spite of its size, governments face difficult decisions to distribute its resources in order to meet all the needs (Wolk, 2007). Currently existing means in which problems are solved are ineffective, and so the market is unable to resolve all economic problems (Kostetska \& Berezyak, 2014). Therefore, governments often seek the partnership and support of citizens, volunteers, nonprofit and private sectors (Wolk, 2007). The nonprofit sector that is a general term for organizations serving the public good, offers goods or services that are not provided by public sector organizations, and that private commercial organizations do not or even cannot provide (Stecker, 2014). As a result of impossibility of business and government causing market failure, social enterprises are emerged to provide partial or active for the problems of society. Generating different tools to combine resources, inventing exchange models, and interacting among people, social entrepreneurs are oriented on social innovation, which is essential for the modern society (Kostetska \& Berezyak, 2014).

The nonprofit sector comes into play when the public and private organizations cannot address a societal need. The nonprofit sector cannot distribute profits to their owner, but rather they use their revenues for sustainability or growth. However, recent trends have reduced the traditional functions of the three sectors combining the social and economic parts that private sector, governmental, and nonprofit organizations are performing (Wolk, 2007). Business is not focused solely on profit, the public sector not only solves market failures, and the nonprofits are expanding their engagement to meet societal needs (Wolk, 2007).

In consequence, social entrepreneurship exhibits characteristic of all three sectors. Wolk (2007) illustrates how these trends created opportunity for social entrepreneurship to develop (Figure 1). 


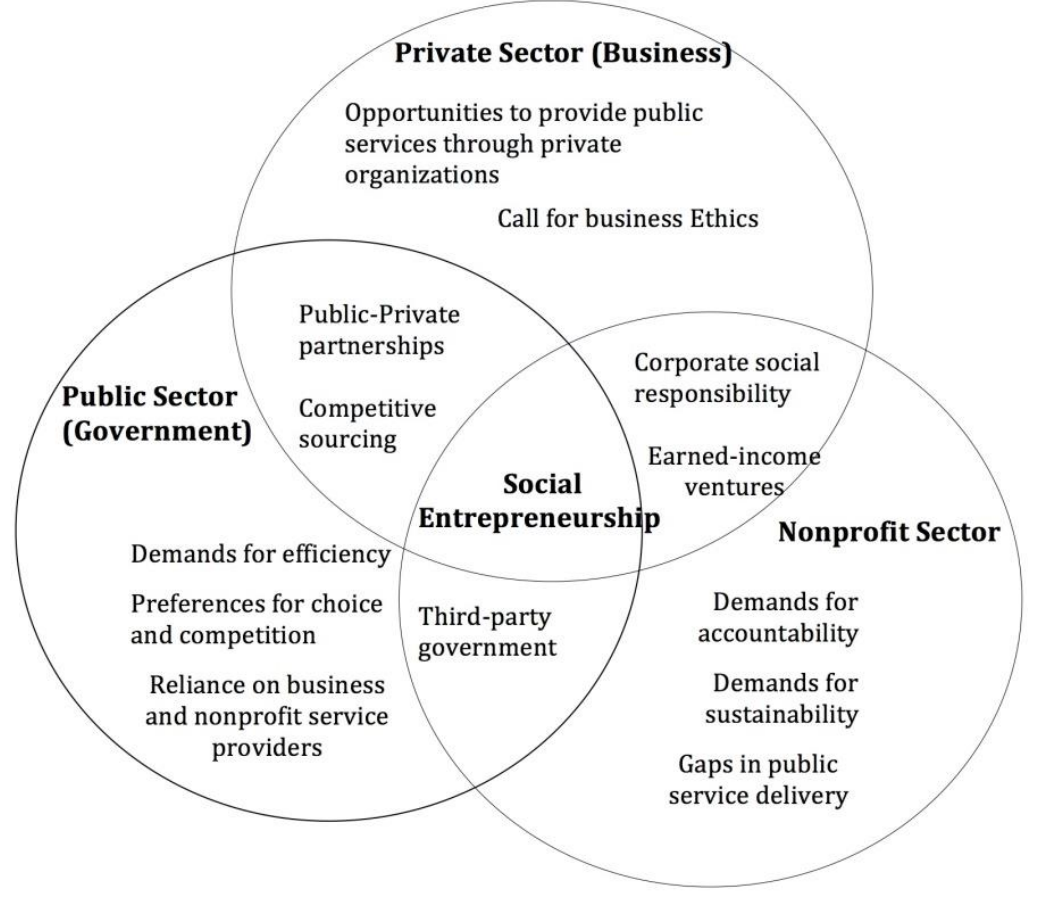

Figure 1. Social Entrepreneurship blurring borders of three sectors

Source: Wolk, 2007.

York (2009) suggests sustainability formula for nonprofit organizations, which is the sum of Leadership, Adaptability, and Program Capacity (Figure 2). The government can contribute in helping organizations to strengthen those skills by providing trainings, relevant information, or education opportunities.

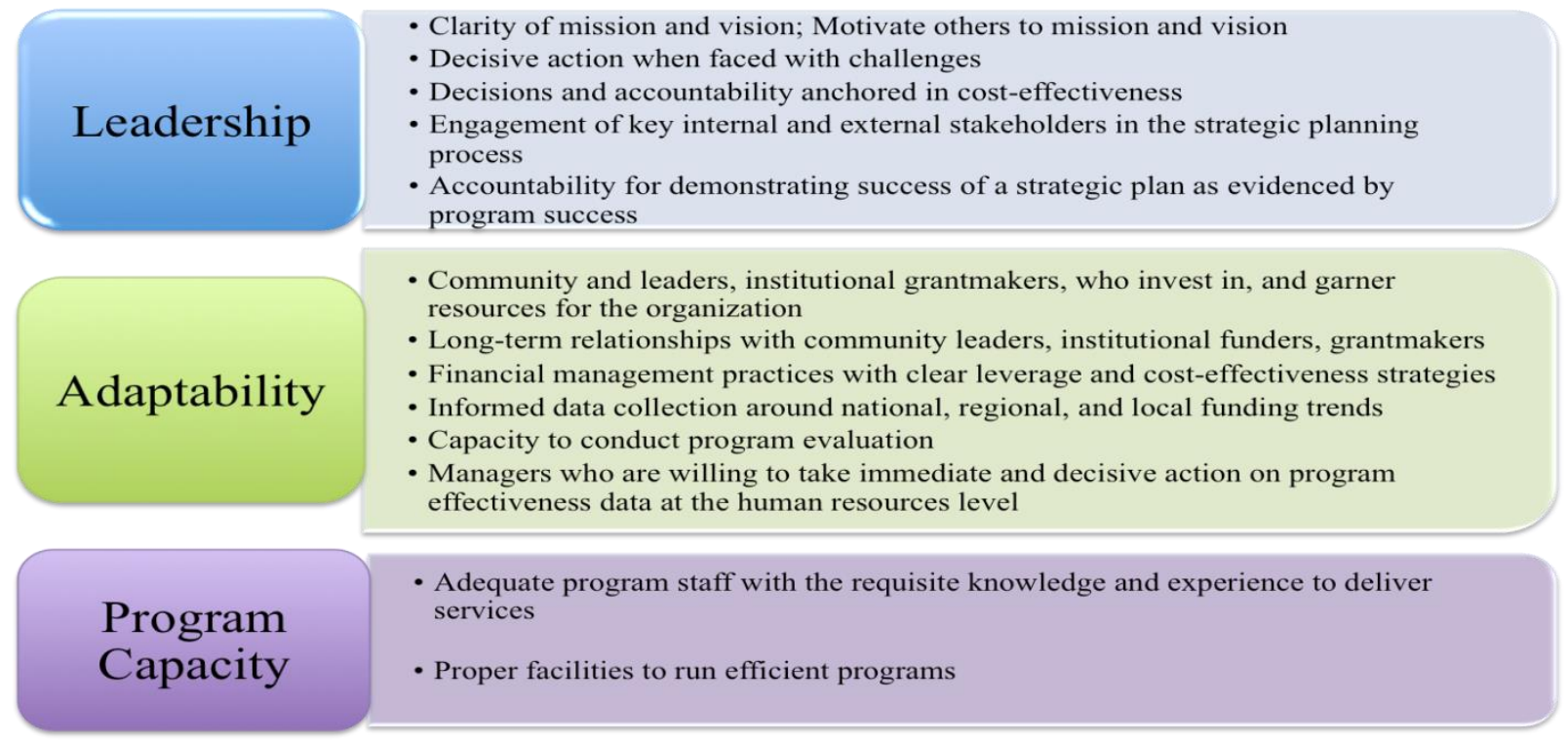

Figure 2. Sustainability formula for nonprofit organizations

Source: York, 2009. 
Although nonprofit sector offers an important service to the communities, it extremely depends on financing of donors and hence is not steady (Stecker, 2014). However, social entrepreneurship can increase their sustainability if they adopt the new business model (Stecker, 2014). The primarily mission focus of social entrepreneurs is social benefits and not profits for shareholders (Bornstein, 2007). Social entrepreneurs challenge unfair systems, address to suffer and inequality by identifying problems and creating innovative solution for the better future (Martin \& Osberg, 2007; Stecker, 2014).

Governments and social entrepreneurs should cooperate to conquer more social problems, but to achieve this they should direct supportive regulatory mechanisms and policy to facilitate and stimulate further development of the SE ecosystem (Bozhikin, 2019).

\section{Social Entrepreneurship Helping Government to Benefit Georgia}

The conception of social entrepreneurship is increasingly gain attractiveness in Georgia owing to the programs of international organizations offering funding grants for establishing social enterprises (Gigauri, 2018).

The popularity of social entrepreneurship, and its potential to solve the intractable social problems (Wolk, 2007) that Georgia currently faces should be in the interest of policymakers. However, the largest funding sources for services addressing these problems are the government.

Development of social entrepreneurship in Georgia started in 2008-09 (Rosandic, Arsenidze \& Khutsishvili, 2018), and since then it has been gradually attracting attention, especially by the civil society organizations. Mainly, nonprofit sector has been engaging in social entrepreneurship, which has established social enterprises with grant support from local and international donors, as well as from the Georgian governmental agencies. In 2009-2018 years, the total amount invested in the social entrepreneurship sector, including start-up, sector promotion, capacity building, technical assistance, is around 2.4 million Euros (Rosandic, Arsenidze \& Khutsishvili, 2018).

In 2018, the nonprofit sector in Georgia employed 52280 people, from which 7648 were employed in health and welfare service (Geostat).

In tote, around 70 entities of non-entrepreneurial (non-commercial) legal entities (NNLE) and Limited Liability Companies (LTD) operate as a social enterprise (Rosandic, Arsenidze \& Khutsishvili, 2018).

Since sources for financing nonprofit/ nongovernmental organizations have been declining as a result of the recession and recent crisis caused by new coronavirus Covid-19, the Georgian nonprofit sector needs to find innovative funding opportunities to their social missions. This leads to establishing social enterprises as self-sustained structures.

The activity of social enterprises in Georgia concentrates mostly socially disadvantaged groups, e.g. persons with disabilities, ex-prisoners, orphans, and on solving the ecological problems, e.g. preserving the environment, recycling, controlling pollution. 


\section{Macrothink}

Business and Economic Research

ISSN 2162-4860

2020, Vol. 10, No. 3

As of 2016, the volume of turnover from the mission-related business activities of NNLE sector was 98.6 million Georgian Lari (GEL) (Rosandic, Arsenidze \& Khutsishvili, 2018).

The data of National Statistics Office of Georgia (Geostat) indicate that 28232 non-commercial legal entities are currently registered in Georgia (Table 2), among which 3 879 are operating.

Table 2. Number of registered and active entities by organizational-legal form (1 April 2020)

\begin{tabular}{|l|l|l|}
\hline Legal Status & Number of Registered entities & Number of Active entities \\
\hline TOTAL & 775097 & 184633 \\
\hline Commercial legal persons & 280167 & 81353 \\
\hline Joint liability companies & 2755 & 203 \\
\hline Limited partnerships & 188 & 22 \\
\hline Limited liability companies & 269016 & 80002 \\
\hline Joint stock companies & 2809 & 918 \\
\hline Cooperatives & 5399 & 208 \\
\hline Non-commercial legal persons & 28232 & 3879 \\
\hline Individual entrepreneur & 454934 & 95587 \\
\hline Other & 5903 & 1144 \\
\hline Entities of public law & 5861 & 2670 \\
\hline
\end{tabular}

Source: Geostat: www.geostat.ge

From 2012 to 2018, number of employed persons of noncommercial organizations has significantly decreased (Figure 3) (Geostat, 2020). Georgian noncommercial/ nonprofit organizations had 81164 employees in 2012, while their amount in 2018 was only 52280. By the same token, the number of persons employed by nonprofit sector decreased from 82832 to 5328 in the last six years.

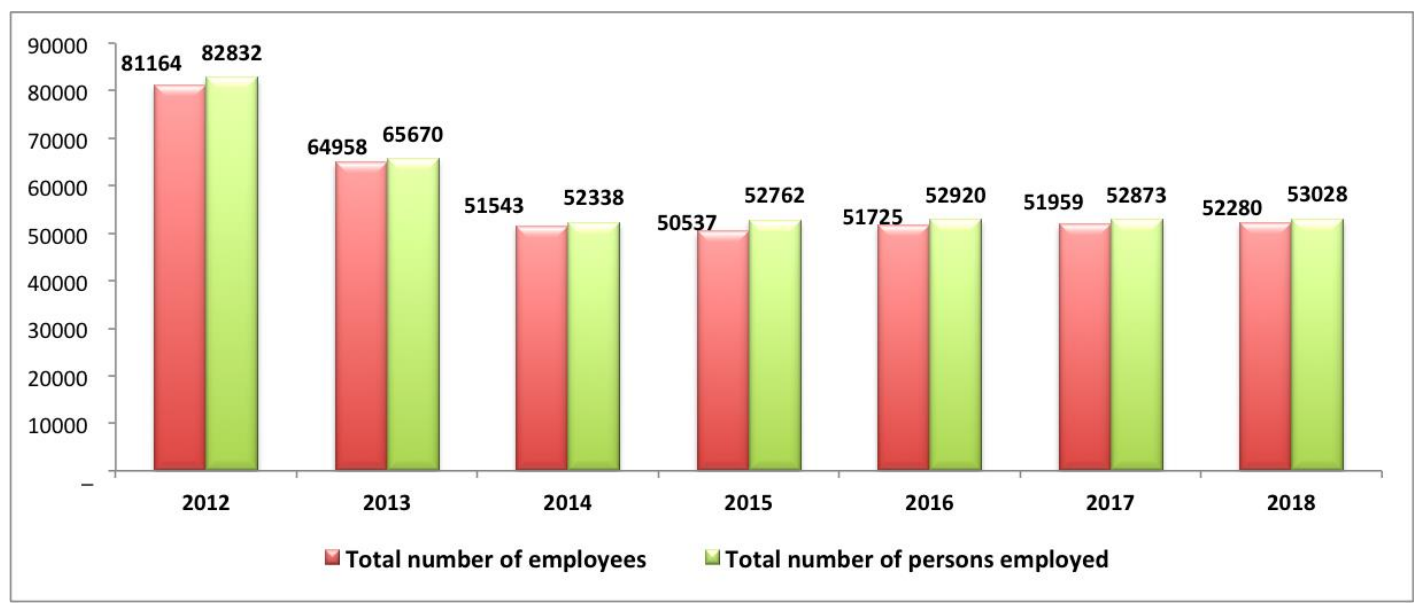

Figure 3. Number of employees and employed persons of noncommercial organizations by kind of economic activities, 2012-2018 years (Geostat) 
Source: Geostat: www.geostat.ge

Subsequently, turnover of noncommercial organizations has reduced as well. However, their production (goods, services) value has augmented (Figure 4). While in 2012 the turnover from economic activities of nonprofit organizations was 198721.1 thousand GEL, it was only 137616.1 thousand GEL in 2018. At the same time, the production value of 811720.1 thousand Gel in 2012 increased considerably to 1077758.8 thousand GEL in 2018.

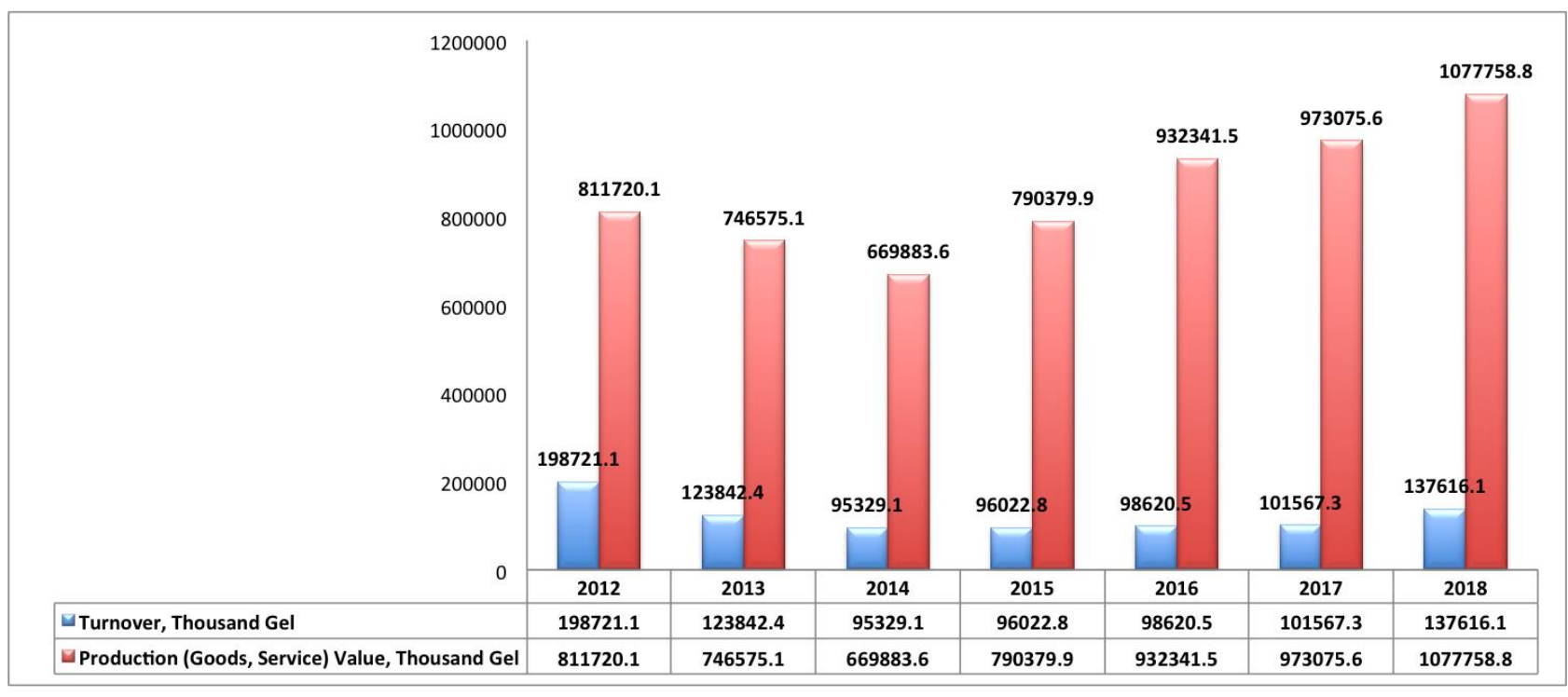

Figure 4. Turnover of economic activities by noncommercial organizations in Georgia Source: Geostat - www.geostat.ge

On the one hand, Georgian central government as well as local municipalities spends their funds to benefit their constituents, to finance social activities aiming at solving societal problems, and to provide social services. On the other hand, the nonprofit sector in Georgia largely relies on financial resources coming from donors that have their specific requirements and objectives. Consequently, the ability of nonprofit organizations to solve urgent social problems is limited as they can only implement projects that are funded by the grant providers. Therefore, future growth of social entrepreneurship is crucial for financial independence, and to enable access to the means that make it possible to scale solutions.

Social entrepreneurs can serve as social problem solving resources for government to improve the lives of Georgian people. Since social entrepreneurs can be efficient and effective in their operations, they can help government to achieve results at low costs. Besides, social entrepreneurs can test innovations and cooperate with the government to produce successful results. In general, government leaders frequently need to allocate tax funds to meet persistent societal needs (Wolk, 2007). Wolk (2007) identified two ways in which social entrepreneurs can work hand in hand with the government to improve the 
wellbeing of the citizens: (1) using both public and private resources, and (2) trying out and creating solutions. These two ways can also be used in Georgia by social entrepreneurs to help government in solving social problems.

First, social entrepreneurs recognize and exploit financial or nonfinancial resources in order to solve problems. As a result, they are able to apply efficient solutions to social issues that have been expensive in the past. Moreover, they also can leverage private finances to supplement public funds, and can even shift costs from public budgets to private resources (Wolk, 2007).

Secondly, social entrepreneurs can develop efficient business model that eventually is self-sustaining by charging insignificant payments from customers as well as divert other recourses from volunteer time and community philanthropic support. In addition, learning process, innovation, and experimentation are required to find solutions for hard social problems. Social entrepreneurs accept challenges, and even experience frequent failures to test innovations. Thus, their value to government is also their progress in developing promising solution by designing new approaches and testing new theories or ideas to address social problems. Social entrepreneurs can take more risk in this regard, which government cannot afford. However, they cannot replace government social programs but can serve as a bridge since they are closer to people. Social entrepreneurs can inspire government to find efficient solutions as well as supply with the needed information to create a social program. Government can benefit from experience and knowledge social entrepreneurs have accumulated (Wolk, 2007).

\section{Encouraging Social Entrepreneurial Innovation in Georgia}

Obviously, social entrepreneurship help government in solving urgent social problems, but government needs also to support social-entrepreneurial initiatives. However, Georgian government does not provide currently much support to social entrepreneurs.

In Georgia, government lacks a strategic approach for collaborating with social entrepreneurs. There are number of ways to work with social entrepreneurs on initiatives addressing societal problems in the country. First, government can provide start-up funds to support social entrepreneurial initiatives, as the initial phase of any organization is decisive to survive. Supporting social entrepreneurs in launching process will encourage founding social enterprises, and also attract young entrepreneurs in this field.

Besides, government can play a proactive and important role in collaboration with social entrepreneurs by organizing or supporting competitions and awards in social innovations. Moreover, government can create an enabling environment by removing barriers especially by law that discourage social entrepreneurship. For example, the Georgian legislation does not recognize social enterprise - people can establish either nonprofit organization or profit company to launch social entrepreneurship. Thus, government should identify and eliminate obstacles to empower social entrepreneurs.

Government leaders can also be helpful in generating media attention to social initiatives, which is a key factor for further success of social entrepreneurship. The environment should 
encourage entrepreneurs to implement new ideas. Another powerful way government rewards social entrepreneurship is through purchasing goods or services social enterprises produce. Finally, government can collaborate with social entrepreneurs by producing knowledge that helps in identifying problems, and setting standards for measure the success.

It is noteworthy that current challenges of social enterprises are more concerned to implement social projects rather than to develop effective business models. If they obtain support from the government in terms of in the form of tax reliefs, financial aid, grants, loans, or a start-up capital, they can achieve profitability and growth. As social entrepreneurship is blurring the "boundaries between the government, nonprofit, and businesses sectors" (Dees \& Anderson 2003), they can better serve social purposes.

Furthermore, tax incentives for charities playsisepa major role in the development the non-profit sector. Its growth can be influential in addressing societal needs, however, its impact on the national level can be increased only when they engage in social entrepreneurial initiatives.

Kostetska and Berezyak (2014) state that for the growth of social entrepreneurship, governments should enable supportive environment, including creating favorable legal and tax conditions to facilitate launching a social business, as well as encouraging interaction among public, private and nonprofit organizations and with citizens (Kostetska \& Berezyak, 2014). For example, during the last years, legislation enabling creation of social enterprises has been passed in several states of the USA, which includes low-profit limited liability companies (L3Cs), benefit corporations (B Corporations), flexible purpose corporations, and social purpose corporations (Stecker, 2014).

Thus, the landscape of entrepreneurship is changing by sustainable business models such as hybrid businesses, which are cutting the borders between for- and non-profit ventures (Stecker, 2014). Hybrid enterprises characterized by the integration of social mission with deriving a profit, make social environmental impact in lieu of maximizing shareholder revenues (Stecker, 2014).

Moreover, public procurement presents another potential to social enterprises taking part in tenders relating especially social or health services but this is possible only under the legislation that considers social, ethical, and environmental criteria when bidding (European Commission, 2016).

In sum, social entrepreneurs are disrupting nonprofit sector also in Georgia. Governments and businesses are not solving the problems of the country, and the most of active nonprofits in Georgia are struggling to survive. In order to achieve a more sustainable business model, more and more nonprofit organizations have been launching social enterprises.

To accelerate the further development of social entrepreneurship in Georgia, government needs to create or improve an enabling legal and tax conditions, particularly in terms of legal forms of social ventures. Besides, tax incentives can help them when market income is not enough to engage in social activities. In addition, social entrepreneurship should be encouraged in rural areas to ensure regional development, especially with financial support or 
loan incentives. Moreover, the formation of a consulting, educational, and information center can help social entrepreneurs to improve business and management skills as well as to prepare and implement business plans. Furthermore, newly established social enterprises can also need consulting support on legal issues.

As a result, collaboration between government leaders and social entrepreneurs can generate numerous benefits for Georgian society. The appearance of social entrepreneurship as a novel area can open a new path where government and society can benefit from social entrepreneurial efforts.

\section{Conclusion}

The article was developed to investigate the relationship between government and social entrepreneurship, and to show that social entrepreneurial initiatives can respond to market failure.

Social entrepreneurs have displayed incredible resultsis in solutions to social problems that governments as well need to manage. However, the support of government is essential to success of social entrepreneurs.

The modern society is characterized by a situation where social entrepreneurs and government leaders could join forces strategically to make changes in society, and to improve lives of today's population.

Social entrepreneurs are currently solving problems in both developed and developing countries. Accordingly, governments in developing countries can benefit by social entrepreneurship to solve social problems with entrepreneurial initiatives.

The factors of the economic and political landscapes are contributing to the expansion of social enterprises in Georgia. However, the government does not take efforts to a coordinated and strategic view to support social entrepreneurship in the country yet. As social entrepreneurs can have significant impact on solution for social problems of society with innovative and efficient ways, Georgian government should support them. Thus, social entrepreneurship deserves more serious attention from the government of Georgia than it has attracted so far.

Social entrepreneurs are able to help government in solving societal problems by finding new recourses and utilizing existing ones. They even can exempt government tax revenues by shifting spending from the state budget to private resources. Government needs to fill gaps caused by market failure, and so address inequalities. For this reason, if should cooperate with social entrepreneurs to provide public goods, which will lead to the private sector and markets to work. Accordingly, social entrepreneurship responds to market failures with innovative tools aimed at addressing societal problems. Social entrepreneurs are able to experiment and eventually develop a sustainable solutions to problems caused by a market failure.

In addition, social entrepreneurs should manage outcomes to show their greater benefits for the society as they transform lives, and demonstrate meaningful, lasting impact. Unlike to 
nonprofit organizations to which "funding requirements may demand that they serve particular populations or reach certain participation levels" (Morino, 2001), social entrepreneurs have more freedom in this regard.

Social entrepreneurship can pave the way to next generations to better satisfy their needs. The concept enables new collaborative efforts between public, private and nonprofit sectors while forming social value. Thus, the distinction between the business and social sectors is becoming progressively smooth, and corporations are also engaging in addressing the challenges faced by society.

Further empirical studies are required to explain how the public agencies can cooperate with social enterprises. It should reveal the methods government could use to inspire social entrepreneurs to innovate and to create enabling environment for their initiatives. Besides, future research should demonstrate tools how the government can reward efforts and performance of social enterprises as well as produce knowledge to help them meet social needs.

\section{References}

Alvord, S. H., Brown, D. L., \& Letts, Ch. W. (2004). Social Entrepreneurship and Societal Transformation: An Exploratory Study. Journal of Applied Behavioral Science, 40(3), 260-282. https://doi.org/10.1177/0021886304266847

Anderson, B. B., \& Dees, G. J. (2006). Rhetoric, Reality, and Research: Building a Solid Foundation for the Practice of Social Entrepreneurship. In Social Entrepreneurship: New Models of Sustainable Social Change, edited by Alex Nicholls, 144-68. London: Oxford University Press.

Ashoka. What is a Social Entrepreneur? [Online] Available:

http://ashoka.org/social_entrepreneur

Barton, Ch., Fromm, J., \& Egan, Ch. (2012). The Millennial Consumer: Debunking Stereotypes. BCG Focus, April. [Online] Available:

https://www.bcg.com/documents/file103894.pdf

Beal, D., Dahl, F., Eisenmann, S., Nowack, D., \& Uekermann, F. (2017). Designing A Social Business That Benefits The Core. BCG Perspective by the Boston Consulting Group.

Bernholz, L., Skloot, E., \& Varela, B. (2010). Disrupting Philanthropy: Technology and the Future of the Social Sector. Center for Strategic Philanthropy and Civil Society, Sanford School of Public Policy, Duke University. [Online] Available:

https://cspcs.sanford.duke.edu/sites/default/files/DisruptingPhil_online_FINAL.pdf

Bornstein, D. (2007). How to Change the World: Social Entrepreneurs and the Power of New Ideas. Oxford University Press.

Bosma, N., Schøtt, Th., Rareness, S., \& Kew, P. (2016). Global Entrepreneurship Monitor (GEM). Special Topic Report Social Entrepreneurship. Global Entrepreneurship Research Association. [Online] Available: www.gemconsortium.org 
Bozhikin, I., Macke, J., \& Da Costa, L. F. (2019). The Role Of Government And Key Non-State Actors In Social Entrepreneurship: A Systematic Literature Review. Journal of Cleaner Production, 226, 730-747. https://doi.org/10.1016/j.jclepro.2019.04.076

Clark, C., Emerson, J., \& Thornley, B. (2012). A Market Emerges: The Six Dynamics of Impact Investing. The Impact Investor. [Online] Available:

http://www.pacificcommunityventures.org/wp-content/uploads/sites/6/2015/07/The_Six_Dyn amics_of_Impact_Investing_October_2012_PCV_CASE_at_Duke_ImpactAssets.pdf

Dees, G. J. (2001). The Meaning of "Social Entrepreneurship". Durham, NC: Duke University. [Online] Available:

https://centers.fuqua.duke.edu/case/wp-content/uploads/sites/7/2015/03/Article_Dees_Meani ngofSocialEntrepreneurship_2001.pdf

Dees, G. J., \& Anderson, B. B. (2003). For-Profit Social Ventures. International Journal of Entrepreneurship Education (special issue on social entrepreneurship), 2, 1-26.

Dees, G. J., \& Anderson, B. B. (2007). Framing a Theory of Social Entrepreneurship: Building on Two Schools of Practice and ought. Association for Research on Nonprofit Organizations and Voluntary Action (ARNOVA) Occasional Paper Series-Research on Social Entrepreneurship: Understanding and Contributing to an Emerging Field. 1(3), 39-66.

Drucker, P. F. (1985). Innovation and Entrepreneurship. New York: HarperCollins.

Geostat. National Statistics Office of Georgia. (2020). [Online] Available:

https://www.geostat.ge/en

Gigauri, I. (2018). Social Entrepreneurship In Developing Countries: Case Of Georgia. The USV Annals of Economics and Public Administration, 18(27), 103-111.

Gruber, J. (2005). Public Finance and Public Policy. New York: Worth Publishers.

European Commission (2012). The Social Business Initiative of the European Commission. Leaflet. [Online] Available:

http://ec.europa.eu/internal_market/publications/docs/sbi-brochure/sbi-brochure-web_en.pdf

European Commission (2016). Social Enterprises and their eco-systems: developments in Europe. Directorate-General for Employment, Social Affairs and Inclusion. Authors: Carlo Borzaga and Giulia Galera.

European Commission (2020) Social enterprises and their ecosystems in Europe. Comparative synthesis report. Authors: Carlo Borzaga, Giulia Galera, Barbara Franchini, Stefania Chiomento, Rocío Nogales and Chiara Carini. Luxembourg: Publications Office of the European Union. [Online] Available: https://europa.eu/!Qq64ny

Fueglistaller, U., Müller, Ch., Müller, S., \& Volery, Th. (2016). Entrepreneurship: Modelle Umsetzung-Perspektiven Mit Fallbeispielen aus Deutschland, Österreich und der Schweiz. Springer Fachmedien Wiesbaden.

Halberstadt, J., Niemand, Th., Kraus, S., Rexhepi, G., Jones, P., \& Kailer, N. (2020). Social 


\section{Ml Macrothink}

Business and Economic Research ISSN 2162-4860 2020, Vol. 10, No. 3

Entrepreneurship Orientation: Drivers Of Success For Start-Ups And Established Industrial Firms. Industrial Marketing Management. https://doi.org/10.1016/j.indmarman.2020.06.012

Kostetska, I. \& Berezyak, I. (2014). Social Entrepreneurship as an Innovative Solution Mechanism of Social Problems of Society. Management Theory and Studies for Rural Business and Infrastructure Development, 36(3). http://dx.doi.org/10.15544/mts.2014.053

Kramer, M. R. (2005). Measuring Innovation: Evaluation in the Field of Social Entrepreneurship. Boston: Foundation Strategy Group.

Light, P. C. (2007). Searching for Social Entrepreneurs: Who They Might Be, Where They Might Be Found, What They Might Do. Association for Research on Nonprofit Organizations and Voluntary Action (ARNOVA) Occasional Paper Series - Research on Social Entrepreneurship: Understanding and Contributing to an Emerging Field, 1(3), 13-37.

Mair, J., \& Marti, I. (2006). Social Entrepreneurship Research: A Source of Explanation, Prediction, and Delight. Journal of World Business, 41, 36-44.

https://doi.org/10.1016/j.jwb.2005.09.002

Markman, G. D., Waldron, T. L., \& Panagopoulos, A. (2016). Organizational Hostility: Why And How Nonmarket Players Compete With Firms. Academy of Management Perspectives, 30(1). https://doi.org/10.5465/amp.2014.0101

Martin, R. L., \& Osberg, S. (2007). Social Entrepreneurship: The Case for Definition. Stanford Social Innovation Review. [Online] Available:

https://ssir.org/articles/entry/social_entrepreneurship_the_case_for_definition

Méndez-Picazo, M-T., Galindo-Martín, M-A., \& Castaño- Martínez, M-S. (2020). Effects Of Sociocultural And Economic Factors On Social Entrepreneurship And Sustainable Development. Journal of Innovation \& Knowledge. https://doi.org/10.1016/j.jik.2020.06.001

Morino, M. (2011). Leap of Reason: Managing to Outcomes in an Era of Scarcity. Venture Philanthropy Partners. https://doi.org/10.1162/INOV_a_00092

Nicholls, A. (2006). Introduction to Social Entrepreneurship: New Models of Sustainable Social Change, edited by Alex Nicholls, 1-35. London: Oxford University Press.

Phills, J., \& Denned, L. (2005). Social Entrepreneurs: Correcting Market Failures (A) and (B). Stanford, CA: Stanford Graduate School of Business Case Writing Office.

Peredo, A. M., \& McLean, M. (2006). Social Entrepreneurship: A Critical Review of the Concept. Journal of World Business, 41(1), 56-65. https://doi.org/10.1016/j.jwb.2005.10.007

Robinson J. (2006). Navigating Social and Institutional Barriers to Markets: How Social Entrepreneurs Identify and Evaluate Opportunities. In J. Mair, J. Robinson \& K. Hockerts (Eds.), Social Entrepreneurship. Palgrave Macmillan, London.

https://doi.org/10.1057/9780230625655_7

Rosandic, A., Arsenide, G., \& Khutsishvili, S. (2018). Social Economy in Eastern Neighbourhood and in the Western Balkans: Country report - Georgia. 
Seelos, Ch., \& Mair, J. (2005). Social entrepreneurship: Creating new business models to serve the poor. Business Horizons, 48(3), 241-246.

https://doi.org/10.1016/j.bushor.2004.11.006

Schumpeter, J. (1982). The Theory of Economic Development. New Brunswick, NJ: Transaction Publishers.

Skloot, E. (1983). Should Not-for-Profits Go Into Business? Harvard Business Review, 61(1), 20-25.

Smith, E. E., \& Aaker, J. L. (2013, December 1). Millennial Searchers. The New York Times.

Stecker, M. J. (2014). Revolutionizing the Nonprofit Sector Through Social Entrepreneurship. Journal of Economic Issues, 48(2), 349-358. https://doi.org/10.2753/JEI0021-3624480208

UN World Food Programme (WTF), (2019). Hunger Map. [Online] Available:

https://www.wfp.org/publications/2019-hunger-map

Villis, U., Strack, R., Yunus, M., \& Bruysten, S. (2013). The Power of Social Business: Lessons from Corporate Engagements with Grameen. BCG The Boston Consulting Group. [Online] Available:

https://www.bcg.com/publications/2013/corporate-social-responsibility-poverty-hunger-powe r-social-business.aspx

Wolk, A. M. (2007). Social Entrepreneurship and Government: A New Breed of Entrepreneurs Developing Solutions to Social Problems. A Root Cause Report. In The Small Business Economy: A Report to the President. Small Business Administration, Office of Advocacy. [Online] Available:

https://rootcause.org/wp-content/uploads/2019/05/Social-Entrepreneurship-and-Goverment.p df

York, P. (2009). The Sustainability Formula: How Nonprofit Organizations Can Thrive in the Emerging Economy. TCC Group. [Online] Available:

http://actrees.org/files/Research/sustainabilityformula.pdf

Yunus, M. (2010). Building Social Business: The New Kind of Capitalism that Serves Humanity’s Most Pressing Needs. New YorkL Public Affairs.

Zahra, S. A., Gedajlovic, E., Neubaum, D. O., \& Shulman, J. M. (2009). A typology of social entrepreneurs: Motives, search processes and ethical challenges. Journal of Business Venturing, 24(5), 519-532. https://doi.org/10.1016/j.jbusvent.2008.04.007

\section{Copyright Disclaimer}

Copyright for this article is retained by the author(s), with first publication rights granted to the journal.

This is an open-access article distributed under the terms and conditions of the Creative Commons Attribution license (http://creativecommons.org/licenses/by/4.0/). 